\title{
SCIENTIFIC VALIDATION AND STANDARDIZATION OF PARPATAKA AN AYURVEDIC DRUG WITH RESPECT TO FUMARIA INDICA
}

\author{
B. JYOTHI ${ }^{1}$, GOLI PENCHALA PRATAP ${ }^{2}$, MOHD KASHIF HUSAIN², MUNAWWAR HUSSAIN KAZMI ${ }^{2}$, G. P. PRASAD ${ }^{3}$, \\ G. SUDARSANAM ${ }^{4}$
}

1Department of Botany, S. P. W. D. and P. G College, Tirupati, Chittoor (Dt), A. P, ${ }^{2}$ Survey of Medicinal Plants Unit (SMPU), Central Research Institute of Unani Medicine (CRIUM) Hyberabad, Telangana, India, ${ }^{3}$ Regional Ayurveda Institute for Fundamental Research, Pune, Maharashtra, India, ${ }^{4}$ Department of Botany, Sri Venkateswara University, Tirupati, Andra Pradesh, India

Email: penchalapratap.goli@gmail.com

Received: 18 Apr 2019, Revised and Accepted: 26 Jun 2019

ABSTRACT

Objective: Fumaria indica is an essential curative herb and asserted as a prevalent weed across the plains of India. The entire plant is popularly employed in conventional systems of medicine for its therapeutic activities like anthelmintic, diuretic, diaphoretic, laxative, purging and stomachic. The entire plant is regarded to have therapeutical purposes in Ayurvedic and Unani systems of medicine and is employed in the preparation of important Ayurvedic formulation Parpataka. In Unani systems of medicine, it is used as shahtara. This contemporary study is intended to authenticate and validate the species Fumaria indica with respect to Parpataka drug.

Methods: The chief objective of this contemporary research work is to assess the various pharmacognostic properties like Macroscopical, Microscopical, Physiochemical and Fluorescence studies. Microscopical studies include cell structure and their arrangement, Physicochemical parameter s include loss on drying, total ash value, acid insoluble ash, water-insoluble ash, various extractive values etc. Qualitative tests for various functional groups were also carried out.

Results: The microscopical characters of leaf, stem and roots, physicochemical, preliminary phytochemical profiles were established.

Conclusion: The pharmacognostical screening on Fumaria indica is significant data for the identification and to determine the quality and purity of the plant material in future reviews.

Keywords: Parpataka drug, Fumaria indica, Macro and microscopical studies

(C) 2019 The Authors. Published by Innovare Academic Sciences Pvt Ltd. This is an open-access article under the CC BY license (http://creativecommons.org/licenses/by/4.0/) DOI: http://dx.doi.org/10.22159/ijcpr.2019v11i4.34958

\section{INTRODUCTION}

Fumaria indica is diuretic, diaphoretic, aperient, laxative and anthelmintic. It is used in low-grade fevers, to purify the blood and also in skin disorders. The plant is bitter, cooling, expectorant, relieves constipation, increases vata, removes indigestion, biliousness, burning of the body, tired feeling, intoxication, urinary discharges, vomiting, thirst, enriches the blood and good in leprosy. Leaves are bitter, cooling, constipating, easily digested, cure bilious fevers, blood diseases, alley thirst, stop wandering of mind [1-2].

The drug is sold in Indian bazars under the name SHAHTERAH or PITPAPRA and used in stomach disorders, liver complaints and skin affections. The dried aerial parts of the $F$. vaillantii Loisel, are used as a substitute for fumitory in North India [3]. It is used in Ayurveda against fevers in Punjab and North India [4]. It is prescribed in the Siddha system of medicine, diuretic, stomachic, purifies the blood in skin diseases, strengthens the teeth and gives luster to the eyes, stops vomiting, good in diseases of the spleen [5]. It is used in Europe as an alternative, aperient, and antifebrile drug in Spain; it is given in visceral obstructions, scorbutic affections and in various eruptive diseases [6].

According to the Ayurvedic Formulary of India [7], Fumaria indica is the accepted source of the parpataka drug. Some others equate it with Rungia repens of the family Acanthaceae [8]. This is the Parpataka of Gujarat and Saurashtra. Other plants equated with the drug are Polycarpaea corymbosa (Caryophyllaceae), Rostellularia procumbens (Acanthaceae), Glossocardia linearifolia (Asteraceae) and Mollugo stricta (Molluginaceae) [9].

In Kerala, however, none of these is accepted as a source of the drug. Instead, three closely similar species of Hedyotis (Oldenlandia), Hedyotis brachypoda (O. brachypoda), H. corymbosa (O. corymbosa) and $H$. diffusa (O. diffusa) are generally accepted [10]. It is evident that, a great controversy in the identification of parpataka drug is noticed. In this connection, the present study was planned to evaluate pharmacognostical profiles of whole plant, which includes macroscopical, microscopical, physicochemical, phytochemical and fluorescence studies. Physicochemical parameters are the important characteristic features of a drug and with the help of this; we can detect the extent of adulteration as well as establish the quality and purity of the drug. There is a considerable difference in the ash values and extract values of different drugs but mostly the difference varies within narrow limits in case of the same drug.

\section{MATERIALS AND METHODS}

The plant specimens, constrained to the present study, were solicited from Hill ranges of Dehradun, Uttarakhand state. It was examined with Herbarium specimen: K. M. Matthew, 166985 (MH) Maximum care was taken in collecting healthy plants. From a healthy sample, different organs were separated meant for the study. Then the separated samples were fixed in FAA. The collected samples were allowed to dehydrate with a graded series of tertiary butyl alcohol only after $24 \mathrm{~h}$ of fixation [11]. Then infiltration of samples was carried out by the progressive addition of paraffin wax (m. p. 58-600C) until TBA solution attained supersaturation. The specimens were permitted to make into paraffin blocks.

\section{Sectioning [11-18]}

The selected samples, which are inserted in the paraffin wax, was sectioned with Rotary Microtome. The section with the thickness of $10-14 \mu \mathrm{m}$ was de-waxed and stained with Toluidine blue. Lignified cells generate blue color, cellulose wall become pink color, suberin becomes dark green, mucilage becomes violet, protein bodies produce blue color etc. and also the necessary sections were stained 
with safranin, fast green and IKI (for starch). Since Toluidine blue is a polychromatic stain, the staining results were exceptionally good, and some cytochemical reactions were also obtained. Photomicrographs Microscopic Pictures of different tissues at multiple magnifications were taken with help of Nikon photomicroscopic unit. Polarized light was utilized for the study of crystals, starch grains, lignified cells, and the bright field was used for normal observations. Scale bars in pictures indicated the microscopic magnification [8].

\section{Physico-chemical studies}

Physical constants like ash values were calculated according to the standard methods [19-23].

\section{Fluorescence studies}

It is one of the essential studies for quality control of drugs and valuable in preparing the standards of the quality of the powdered drug. The fluorescence study of powdered drugs as a method of identification seems to possess distinct probabilities of practical application

\section{Preliminary phytochemical studies}

The whole plant was thoroughly washed and a sufficient quantity of the sample was collected and chopped off into small pieces and shade dried. The dried parts were pounded to make a coarse powder and stored in polythene containers for further analysis.

\section{Alkaloids}

The methanol extracts were evaporated to dryness and the residue obtained was digested with $1 \%$ hydrochloric acid. The resulting acidic solution was divided into two parts. To one part was added Mayer's reagent and to the second part Dragendorff's reagent. Appearance of precipitate or turbidity indicates the presence of alkaline preparation of reagents.

a. Mayer's reagent: $1.3 \mathrm{~g}$ of mercuric chloride and $5 \mathrm{~g}$ of potassium iodide were dissolved separately in $60 \mathrm{ml}$ and $10 \mathrm{ml}$ of double distilled water and both the solutions were mixed and diluted to 100 $\mathrm{ml}$.

b. Dragendorff's reagent: $8 \mathrm{~g}$ of the bismuth nitrate was dissolved in $20 \mathrm{ml}$ of con. nitric acid and $27.2 \mathrm{~g}$ of potassium iodide in $50 \mathrm{ml}$ of double distilled water. Both the solutions were allowed to stand till $\mathrm{KIO}_{3}$ crystallized out. Supernatant was decanted and the final volume was adjusted to $100 \mathrm{ml}$.

\section{Flavonoids (Shinoda's test)}

a. The plant extract was tested for flavonoids by Shinoda's reaction. To a few $\mathrm{ml}$ of methanolic extract, con. hydrochloric acid, magnesium powder and a few fragments of magnesium metal were added. The presence of flavonoids was identified by the development of pink or magenta or red coloured flame.

b. To a few $\mathrm{ml}$ of methanolic extract, $10 \%$ sodium hydroxide solution and ammonia were added. Dark yellow colour indicates the presence of flavonoids.

\section{Terpenoids (Noller's test)}

To $1 \mathrm{ml}$ of the methanolic extract with tin (one bit) and thionyl chloride was added. Appearance of pink colour indicates the presence of terpenoids.

\section{Liebermann-Burchard's test}

The Liebermann Burchard's reaction was carried out by adding 0.5 $\mathrm{ml}$ of $\mathrm{H}_{2} \mathrm{SO}_{4}$ along the side of the test tube containing a mixture of methanolic $\mathrm{HCl}$ and acetic anhydride $(0.5 \mathrm{ml}$ each). Formation of colour from green to bluish-green (sometimes via red or blue) indicates the presence of terpenoids.

\section{Detection of steroids (Liebermann-Burchard's test)}

To $1 \mathrm{ml}$ of extract $0.5 \mathrm{ml}$ of chloroform, $5 \mathrm{ml}$ of acetic anhydride and $5 \mathrm{ml}$ of acetic acid added, followed by a few drops of con. $\mathrm{H}_{2} \mathrm{SO}_{4}$. Development of blue-green colour indicates the presence of steroids.

\section{Detection of saponins}

To $1 \mathrm{ml}$ of the extract, $5 \mathrm{ml}$ of tap water was added and shaken vigorously. Formation of honeycomb, like froth, indicates the presence of saponins.

\section{Detection of tannins}

The methanolic extract was concentrated and the residue was dissolved in water and tested with $1 \%$ gelatin solution and $1 \%$ of gelatin salt solution ( $1 \mathrm{~g}$ gelatin dissolved in $10 \mathrm{~g} \mathrm{NaCl} \mathrm{w/w)} \mathrm{to}$ separate volumes. The appearance of white precipitate indicates the presence of tannins.

\section{Proteins (Biuret test)}

A small quantity of extract dissolved in few $\mathrm{ml}$ of water, equal column of $5 \%$ sodium hydroxide and $1 \%$ copper sulphate solution was added. Formation of violet purple colour indicates the presence of proteins.

\section{Carbohydrates}

a. The extract was mixed with Fehling's solution I and II and examined for the appearance of red coloration for the presence of sugars.

b. Molish Test: To the methanolic extract, $\alpha$-naphthol solution was added. Then conc. $\mathrm{H}_{2} \mathrm{SO}_{4}$ was added gently along the walls of the inclined test tube. Formation of a red to violet colour indicate the presence of carbohydrates.

\section{Phenolic compounds}

To $1 \mathrm{ml}$ of the extract, $2 \mathrm{ml}$ of distilled water was added followed by 1-4 drops of $1 \%$ aqueous ferric chloride. Appearance of blue or green colour indicates the presence of phenols.

\section{Anthocyanidins}

The formation of red or purple colour in the plant extract, on adding an equal volume of methanolic $\mathrm{HCl}$ was taken as a positive reaction for anthocyanidins.

\section{Anthraquinones}

Twenty $\mathrm{ml}$ of benzene was added to $5 \mathrm{~g}$ of plant powder and filtered. To the filtrate $5 \mathrm{ml}$ of $10 \%$ ammonium hydroxide solution was added and shaken well. The formation of pink, red, violet colour in the ammonical phase indicate the presence of anthraquinones.

\section{Lignans}

a. The plant extract was tested for the presence of lignans by adding con. $\mathrm{HCl}$ and $2 \%$ formaldehyde. Development of red colour indicates the presence of lignans.

b. The development of violet colour in the methanolic extract on adding Enrilich reagent is considered as a positive reaction test.

\section{Indoles}

The development of violet colour in the methanolic extract on adding Enrilich reagent is considered as a positive reaction test.

\section{Quinones}

To $1 \mathrm{ml}$ of extract $1 \mathrm{ml}$ of con. $\mathrm{H}_{2} \mathrm{SO}_{4}$ was added. Formation of red colour shows the presence of quinones.

\section{Glycosides}

The extract was mixed with a little anthrone on a watch glass. One drop of con. $\mathrm{H}_{2} \mathrm{SO}_{4}$ was added and made into a paste, warmed gently over the water bath. The presence of glycosides was identified by dark green colour.

\section{Test for gums}

The extract mixed with water gives the thickening of the substances, indicates the presence of gum.

\section{Test for fixed oil}

A small quantity of powder/extract pressed between the filter papers. Formation of grease spot indicates the presence of fixed oils and fats. 


\section{Test for reducing sugars}

To $5 \mathrm{ml}$ of extract, $5 \mathrm{ml}$ of benedicts reagent was added. The tubes were incubated in boiling on a water bath for 10-30 min. The formation of an orange-red precipitate indicated the presence of reducing sugars.

\section{RESULTS}

Taxonomy: (Plate 1)

Fumaria indica (Hausskn.) pug

Family: Fumariaceae

Regional names

Hin.: Pitpapra, Pitpapa, Pitpapda, Shahatra.

San.:Araka, Kalapanga, Charaka, Nakra,

Katupatra, Kavachanamaka, Krishnashakha, Ksheparpata, Panshu, Panshu Paryaya, Parpata, Parpataka, Pragandha, Pittari, Renu, Shita, Shitavallabha, Sutikta, Tikta, Trishnari, Triyashti, Varatikta, Varmakantaka.

Arab: Baglatul mulk, Bulslatul mulik, Sahatraja, shahtara

Ben.:Bansulpha

Bom.:Pitpatra

Chin.:Tuyshatuchain

Dec.:Pitpara, Shatra

Eng.:Fine-leaved fumitory

Ger.:Erdrauch

Guj.:Pattapapdo

Kan.:Parpataka

Kash.:Shahterah

Mar.:Pitpada

Nepa.:Kairuwa

Per.:Shahatra, Shatra

Sinh.:Pathapadagam

Tam.:Thura

Tel.:Chatharasi

Urd.: Shahtara

\section{Abbreviations}

Ara.: Arabic; Ben.: Bengali, Bom.: Bombay Presidency; Chin.: Chinese; Eng.: English; Cey.: Ceylon; Ger.: German; Fre.: French; Guj.: Gujarati; Hin.:Hindi; Kan.:Kannada, Kash.: Kashmiri; Mal.:Malayalam; Mar.: Marati; Nepa.: Nepali, Ori.: Oriya; Per.: Persian; San.: Sanskrit; Sinh.: Sinhalese, Tam.: Tamil, Tel.: Telugu, Urd.:Urdu

\section{Part used: Whole plant.}

Fumaria indica (Hausskn.) Pug. J. Linn. Soc. Bot. 44: 313. 1919. Jafri in Nasir and Ali, Fl. W. Pakistan 73: 39. 1974; Matthew, Ill. Fl. Tamil Nadu Carnatic t. 24. 1982. F. vaillantii Lois. J. Bot. (Desvaux) 2: 358. 1809, var. indica Hausskn. Flora 56: 443. 1873. F. parviflora ssp. vaillantii (Lois) Hook. f. Fl. Brit. India 1: 128. 1872. F. parviflora auct. non Lam: Wight and Arn. Prodr. fl. Ind. orient. 18. 1834; Wight, Ill. Ind. Bot. 5. 11 (bis) A: 1840; Gamble, Fl. Madras 1: 36(26), 1915: Fyson, Fl. s. Ind. hill stat. 19. 1932; Matthew, Mat. Fl. Tamil Nadu Carnatic 139. 1981.

Annual diffuse herb, branchlets grooved, puberulous. Leaves 2-3 pinnatisect, $5-7.5 \mathrm{~cm}$, segments 0.5 to $1.5 \mathrm{~cm}$, membranous, base obtuse, margin entire, apex acute, mucronulate, petiole 6 to $8 \mathrm{~mm}$. Raceme terminal, leaf-opposed, to $2.5 \mathrm{~cm}, 10-16$ flowered, peduncle to $4 \mathrm{~cm}$, pedicel $2 \mathrm{~mm}$. Flowers small, white or pink, with purple tips to the petals.
Sepals 2, ovate to $2 \mathrm{~mm}$. Petals $2+2$ with purplish tips, oblong to $7 \mathrm{~mm}$. Stamens diadelphous, $3+3$, staminal sheath subulate above, to $4 \mathrm{~mm}$. Ovary one-celled, ovoid, $1 \mathrm{~mm}$, ovules 1 or 2, on parietal placentation, style filiform, to $4 \mathrm{~mm}$, stigma 2-lobed. Fruits indehiscent, globose, to 2 mm, 1-seeded.

\section{Fl. and Frt: October-March}

Herbarium specimen examined: K. M. Matthew, 166985 (MH)

Distribution: India through to Central Asia. Lands in Telangana[23] and Vijayanagaram districts[24].

\section{Macro and microscopical characters of root}

\section{Macroscopical characters}

Roots are elongated, taproot thick, lateral roots are slender, root measures $0.2 \mathrm{~cm}$ in diameter, taste bitter.

\section{Microscopical characters}

Transverse section of the mature root is circular in outline and shows crushed cortex and secondary phloem measuring $100 \mu \mathrm{m}$ in width. Surface is rough and shallow-fissured. Primary xylem is diarch and the secondary xylem occur in two broad triangular rings. Secondary xylem consists of vessels and xylem fibres. Vessels are wider, thick walled, angular and are mostly in radial multiples. Widest vessel is $100 \mu \mathrm{m}$ in diameter and the narrow vessel is $30 \mu \mathrm{m}$ in diameter. In between the two xylem wings and opposite to the protoxylem points, parenchymatous vascular rays are present (fig. 1).

\section{Root-diagnostic characters}

1. Presence of crushed cortex.

2. Diarch condition of xylem.

3. Secondary xylem occurs in two broad triangular wings.

4. Secondary xylem consists of thick radial bands of vessels and xylem fibres.

\section{Macro and microscopical characters of stem \\ Macroscopical characters}

Branches grooved, $0.3 \mathrm{~cm}$ in diameter, taste bitter and no specific odour.

\section{Microscopical characters}

Transverse section of the stem is uneven in its outline and shows epidermis, cortex and stelar region. There is a wide elliptical pithcanal surrounded by vascular bundles (fig. 2).

Epidermis is made up of narrowly oblong, thin-walled rectangular cells. Cortex is narrow less conspicuous. Around the circumference of the stem, three large fan-shaped vascular bundles and two smaller, radially elongated bundles lying in between larger ones. Larger bundles have wide band of radial rows of vessels and xylem fibres. Vessels are thinwalled, elliptical and in radial chains. Phloem occurs as a thin zone on the outer border of the bundle; small nests of fibres are also present in the cortex. There are about 10 cortical sclerenchyma strands all around the stem (fig. 3,1.2). Smaller bundle has a few vessels and a small cluster of phloem. Ground tissue consists of large, thin-walled compactly arranged parenchymatous cells (fig. 3: 1,2).

\section{Stem-diagnostic characters}

1. Cortex is narrow and less conspicuous.

2. Small nests of fibers are seen in the cortex

3. Ground tissue is made up of large, thin-walled compactly arranged parenchyma.

4. There is a wide elliptical pith-canal surrounded by vascular bundles.

\section{Macro and microscopical characters of leaf}

\section{Macroscopical characters}

Leaves dorsiventral 2-3 pinnatisect $5-7.5 \mathrm{~cm}$, segments $0.5-1.5 \mathrm{~cm}$, taste bitter and no characteristic odour. 


\section{Microscopical characters}

Leaf is shrunken and the ground tissue is collapsed as a result of which the cross-sectional outline of the leaf is irregular. There is a prominent, fairly large median vascular bundle and two lateral vascular bundles. Xylem elements consist of wide, circular vessels. Ground tissue is made up of thin-walled parenchyma cells. (fig. 4.1) (fig. 4, 2.3)

\section{Leaf-diagnostic characters}

1. Xylem elements consist of wide, circular vessels.

2. Ground tissue is made up of thin-walled parenchymatous tissue.

\section{Histochemical tests}

The sections were treated with different reagents and the observations are provided in table 1.

Table 1: Histochemical tests

\begin{tabular}{llll}
\hline Drug & Reagents & Test for & Reaction \\
\hline Section & Iodine solution & Starch & Blue colour \\
Section & Ferric chloride solution & Tannin & Black \\
Section & Sudan III solution & Oil globules & No effervescence \\
Section & Phloroglucinol+dil. HCl+Alcohol & Lignin & Magenta \\
Section & Conc. HCl & Crystals & No effervescence \\
\hline
\end{tabular}

$+=$ Present; -= Absent

Table 2: Powder characteristics

\begin{tabular}{llll}
\hline Name of the plant & Colour & Appearance & Odour \\
\hline Fumaria indica & Pale brown & Fine powder & No Characteristic smell \\
\hline
\end{tabular}

Table 3: Powder analysis

\begin{tabular}{ll}
\hline Treatment & Fumaria indica \\
\hline Powder treated with water & Non-sticky \\
Powder shaken with water & Foam like froth \\
Powder treated with 5\% aqueous NaOH & Brown \\
Powder treated with 60\% aqueous sulphuric acid & Reddish brown \\
Powder pressed between filter paper for 24h & No oil stain \\
\hline
\end{tabular}

Table 4: Ash values

\begin{tabular}{|c|c|c|c|c|}
\hline Name of the plant & Total ash (\%) & Water soluble ash (\%) & Alkalinity of water soluble ash (ml) & Acid insoluble ash (\%) \\
\hline Fumaria indica & 21.7 & 4.32 & 2.17 & 6.84 \\
\hline
\end{tabular}

Table 5: Extractive values

\begin{tabular}{llll}
\hline Name of the plant & $\begin{array}{l}\text { Alcohol soluble extract } \\
(\% \mathbf{w} / \mathbf{w})\end{array}$ & $\begin{array}{l}\text { Water soluble extract } \\
(\% \mathbf{w} / \mathbf{w})\end{array}$ & $\begin{array}{l}\text { Hexane soluble extract } \\
(\% \mathbf{w} / \mathbf{w})\end{array}$ \\
\hline Fumaria indica & 1.6 & 3.90 & 0.9383 \\
\hline
\end{tabular}

Table 6: Fluorescence analysis of various extracts

\begin{tabular}{lll}
\hline Extract & Treatment & Fumaria indica \\
\hline Alcohol (ethanol) & Daylight & Yellowish green \\
& Short UV & Fluorescent yellow \\
Water & Yong UV & Redlow \\
& Daylight & Green \\
& Short UV & Black \\
Hexane & Long UV & Yellowish green \\
& Daylight & Fluorescent green \\
Chloro-form & Phort UV & Dareen on olive \\
& Long UV & Green \\
& Daylight & Black \\
\hline
\end{tabular}

+Present; -Absent

Table 7: Fluorescence analysis of Fumaria indica

\begin{tabular}{lll}
\hline Experiments & Visible/Day light & UV Light \\
\cline { 2 - 3 } & & $\mathbf{2 5 4 \text { nm }}$ \\
\hline Drug powder & Pale brown & Pale green \\
Drug powder+1 N NaOH (aq.) & Brown & Pale green \\
Drug powder+1 N NaOH (alc.) & Brown & Green \\
Drug powder+1 N HCl & Brown & Pale green \\
Drug powder+50\% $\mathrm{H}_{2} \mathrm{SO}_{4}$ & Reddish brown & Green \\
Drug powder+50\% $\mathrm{HNO}_{3}$ & Reddish orange & Fluorescent green \\
Drug powder+Picric acid & Brown & Fluorescent yellow \\
Drug powder+Acetic acid & Brown & Black \\
Drug powder+Ferric chloride & Green & Black \\
Drug powder+HNO & Black & Yellow \\
\hline
\end{tabular}


Table 8: Preliminary phytochemical analysis

\begin{tabular}{|c|c|}
\hline Name of the secondary metabolites & Fumaria indica \\
\hline Alkaloids & + \\
\hline Terpenes & + \\
\hline Steroids & + \\
\hline Tannins & + \\
\hline Saponins & + \\
\hline Flavonoids & + \\
\hline Quinones & + \\
\hline Anthraquinones & + \\
\hline Phenols & + \\
\hline Proteins & - \\
\hline Carbohydrates & + \\
\hline Glycosides & + \\
\hline Gum & + \\
\hline Fixed oils or Fats & + \\
\hline Lignans & + \\
\hline Anthocyanidins & + \\
\hline Indoles & + \\
\hline Reducing sugars & + \\
\hline
\end{tabular}

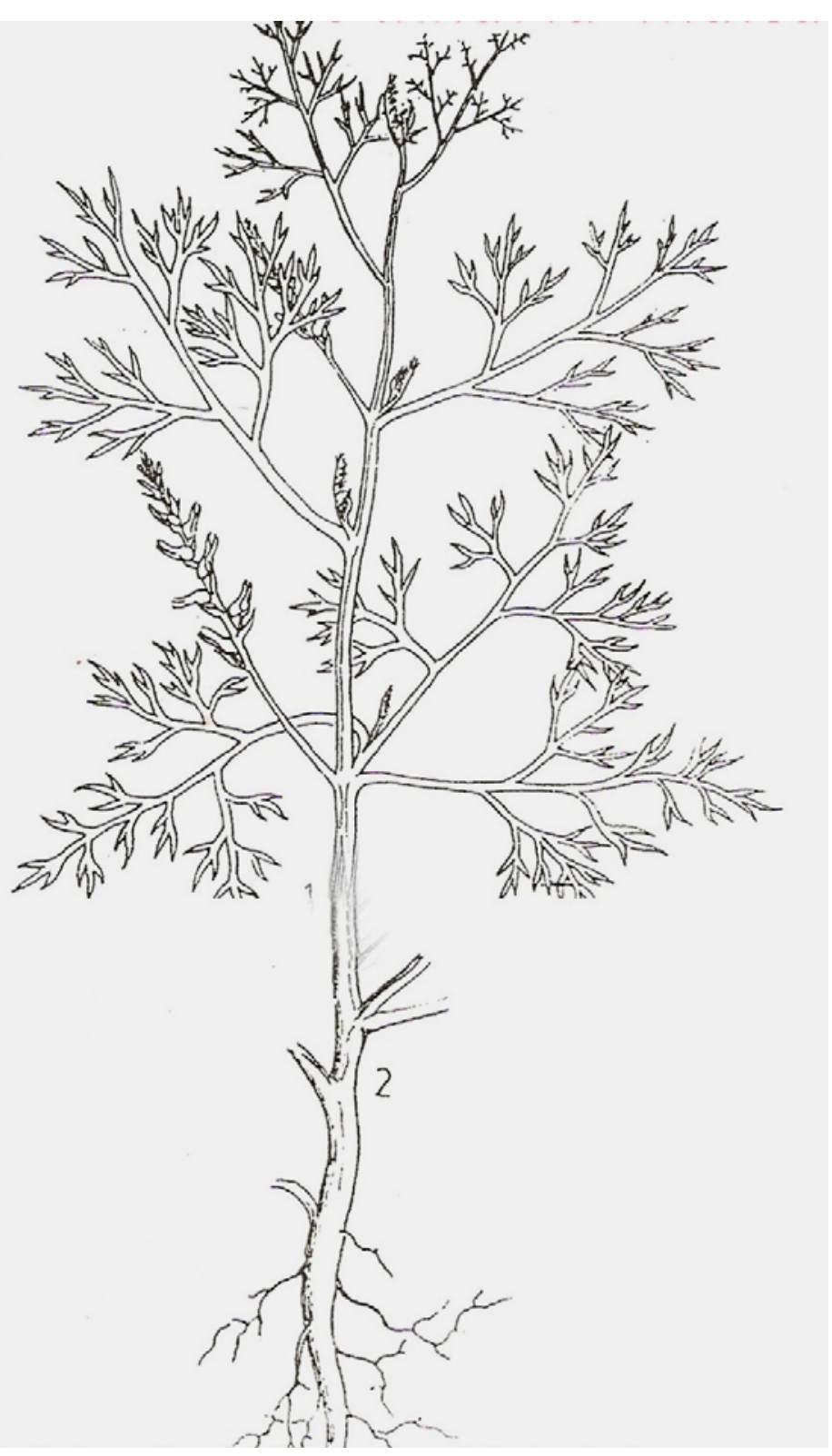

Plate 1: Fumaria indica (Hassk.) Pug. (Fumariaceae), Adopted from Ayurvedic Drugs and their plant sources V.V. Sivarajan and Balachandran. I (1994) 


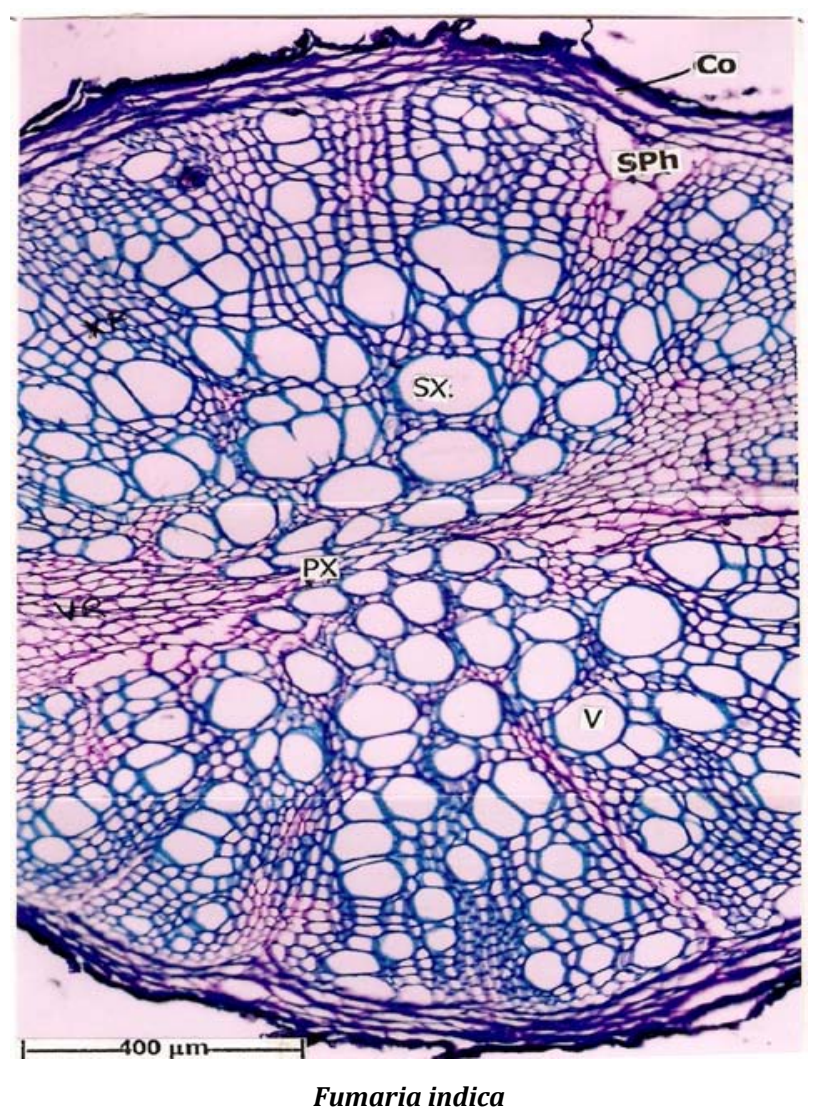

Fig. 1: Microscopical characters of Root

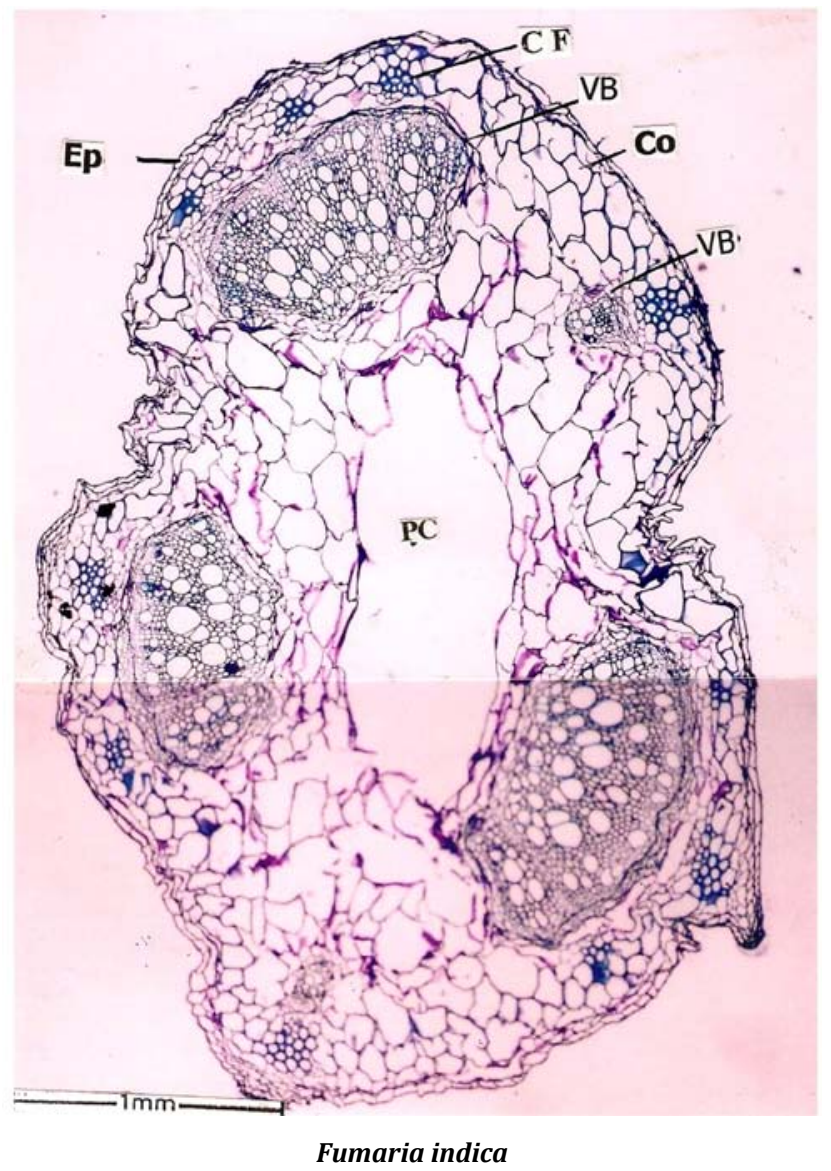

Fig. 2: Microscopical characters of stem-entire view 

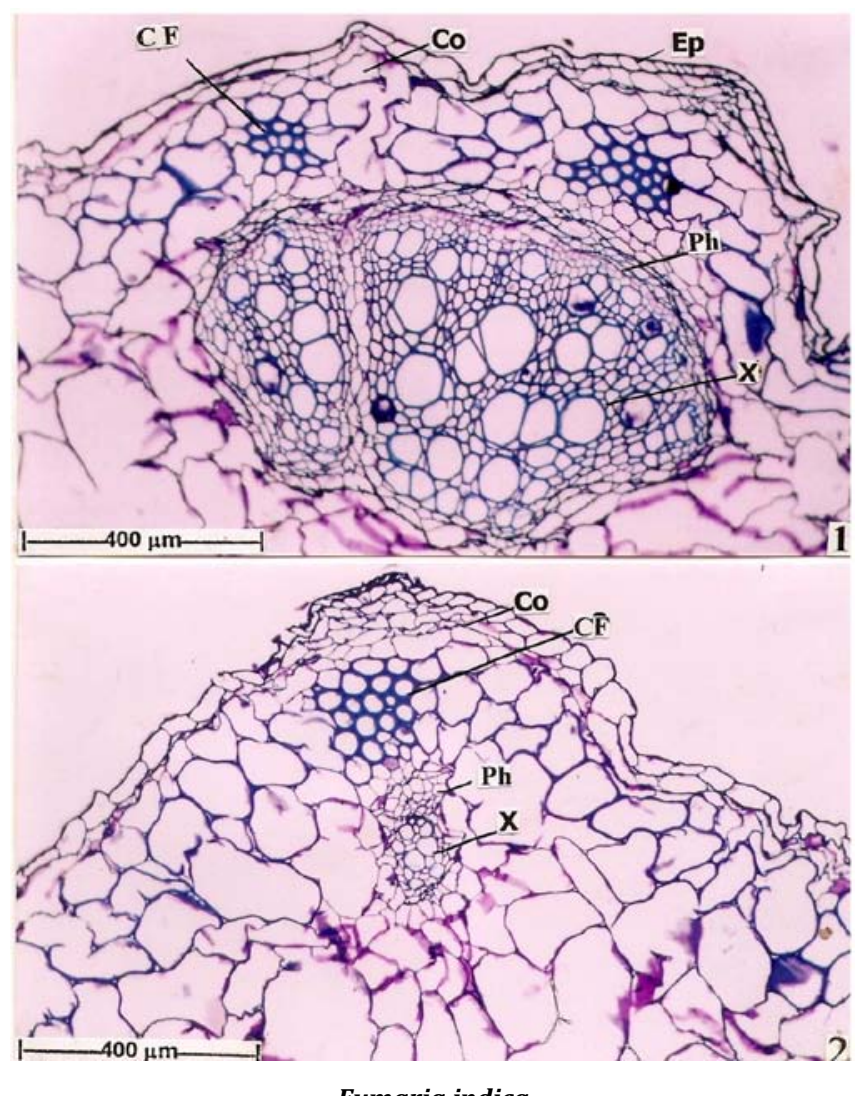

Fumaria indica

Fig. 3: T. S. of Stem-Structure of Vascular bundles, 1. One larger bundle enlarged, 2. One Smaller bundle enlarged

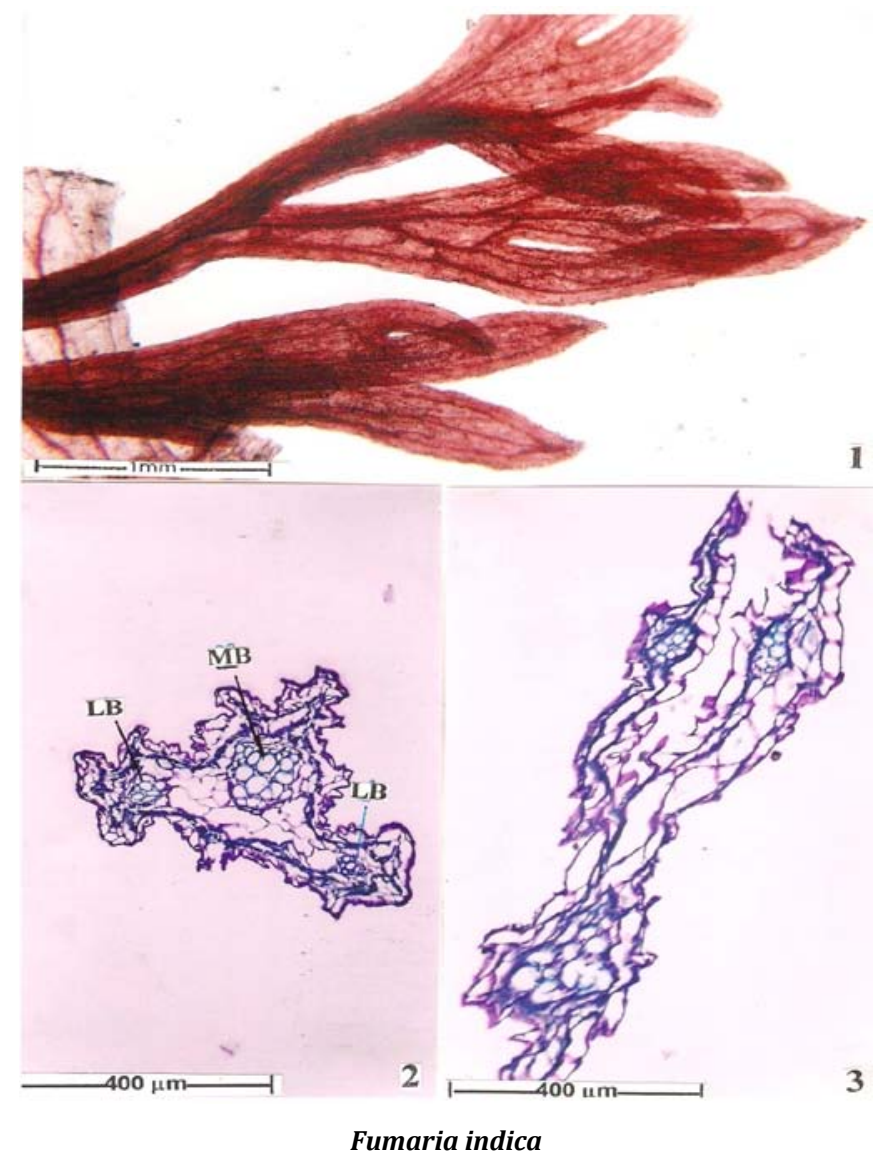

Fig. 4: Venation pattern and microscopical characters of leaf, 1. Venation pattern, 2. T. S. of petiole region, 3. T. S. of leaf with lamina 


\section{DISCUSSION}

Drugs came into existence from very early times to alleviate pain and cure diseases. The traditional systems of medicine like Ayurveda and Siddha derive more than $85 \%$ of the drugs from the plant source. Hence identification of drugs is of paramount importance for the survival of these systems of medicine. However, the correct botanical identification of the several drug materials mentioned in Ayurveda and Siddha have remained a problem until today. One of the important problems in Ayurveda and Siddha is the use of more than one botanical source for the same drug and these different botanical sources are claimed to possess similar therapeutic efficacy by the Ayurvedic and Siddha physicians. Such drugs are termed as controversial drugs in Ayurveda. It is also found that quite often substitutes and adulterants are sold in the crude drug markets from where present-day physicians and drug manufacturers procure their raw drug requirements. Thus, there is an urgent need to undertake standardization of drugs in Ayurveda and Siddha based on scientific parameters like taxonomical, pharmacognostical and phytochemical evaluation. The various exomorphic characters found in the plants/drugs help in the taxonomic method of identification. The several endomorphic characters found in the part used help in the pharmacognostical identification while phytochemical screening provides parameters for identification of the drug in powder form.

The present study deals with the studies on standardization of the controversial Ayurvedic drug Parpataka with the respect of Fumaria indica. Parpataka is a well-known Ayurvedic drug, esteemed as a specific remedy for all types of fevers. The drug is diuretic, anthelmintic, digestive and constipating. The accepted botanical source of the drug is Fumaria indica [7].

Fumaria indica is annual diffuse herb with small flowers white or pink, with purple petals, confined to India. Whole plant is used as drug. Roots are bitter, characterized by crushed cortex, diarch condition of primary xylem and secondary xylem in two broad triangular bands. The stem is bitter, cortex narrow and less conspicuous, small nests of fibres observed in cortex, pith surrounded by vascular cylinder. Leaf is bitter, ground tissue made up of thin-walled parenchyma and there is a prominent median vascular bundle and two lateral vascular bundles. Histochemical tests, Powder characteristics, Powder analysis, Ash values, Extractive values, Fluorescence analysis of various extracts were established results are included in table 1-7.

\section{CONCLUSION}

In conclusion, the present studies have revealed the macro-, and microscopical characters, physicochemical, florescence and phytochemical parameters are essential for providing authentic scientific characterization and identification of the Fumaria indica used in Ayurveda and Siddha systems as a source of Parpataka drug. Such parameters also help in establishing pharmacopoeial standards, which are urgently required not only for the survival of the age-old traditional system of medicine but also in view of the fact that these systems are attaining global importance.

\section{AUTHORS CONTRIBUTIONS}

All the author have contributed equally

\section{CONFLICT OF INTERESTS}

Declare none

\section{REFERENCES}

1. Chopra RN, SL Nayar, IC Chopra. Glossary of Indian Medicinal Plants, New Delhi; 1956.

2. Nadkarni AK. Indian Materia Medica, Bombay; 1954

3. Bapalal V. Some controversial drugs in Indian Medicine, Chowkambha, Varanasi; 1982.

4. Anonymous. The Wealth of India (Raw materials) C. S. I. R, New Delhi. Vol. IV; 1956. p. 68-141.

5. Yoganarasimhan SN. Medicinal plants of India, Karnataka, Interline Publishing Private Limited, Bangalore; 1996.

6. Kirtikar KR, Basu D. Indian medicinal plants with illustrations, Dehradun, Uthranchal. Vol II, V, VIII; 2003. p. 328, 1650, 1651, 1652, 2613, 2626, 2677.

7. Anonymous. The Ayurvedic Formulary of India. Pt-I Controller of Publications, New Delhi; 1978.

8. Kapoor SL, Mitra R. Herbal drugs in Indian pharmaceutical industry, Lucknow; 1979.

9. Chunekar KC. Bhavaprakasanighantu, Chowkambha Bharati Academy Varanasi; 1982. p. 323-7.

10. Kirtikar KR, Basu D. Indian Medicinal Plants, Allahabad; 1918.

11. Sass JE. Elements of botanical microtechnique. Mc Graw Hill Book Co. New York; 1940. p. 222-6.

12. Esau and Katherine. Anatomy of Seed Plants. John Wiley and Sons, New York; 1977. p. 767.

13. Gibbs RD. Chemotaxonomy of flowering plants. Vol. 1-7. McGill Queen's University Press: London; 1974.

14. Harborne JB. Phytochemical methods. A guide to modern techniques of plant analysis. (3rd edition) Chapman and Hall Publications, London; 1973.

15. Johansen DA. Plant microtechnique. New York: McGraw-Hill Book Company, Inc; 1940.

16. Gokhale SB, Kokate CK. Practical pharmacognosy. (13th edition). Nirali Prakashan; 2009.

17. Kokoski CJ, Kokoski RJ, Salma FJ. Fluorescence of powdered vegetable drugs under ultra-violet radiation. J Am Pharm Asson 1958;47:715-7.

18. Penchala Pratap G, Sudarsanam G, Prasad GP. Microscopical observations on cissus vitiginea L. Int J Ayur Pharma Res 2014;2:47-58.

19. Anonymous. Pharmacopoeia of India (Repr. Edition). Controller of Publications, New Delhi; 1985.

20. Anonymous. Phytochemical investigation of certain medicinal plants used in Ayurveda, Central Council for Research in Ayurveda and Siddha, New Delhi; 1990.

21. Chase CR, Pratt RJ. Fluorescence of powdered vegetable drugs with particular resource to the development of a system of identification. J Am Pharm Assoc 1949;38:324-31.

22. Sayeeduddin M. A further contribution to some of the common flowering plants of Hyderabad State, their distribution and economic importance. J Bombay Nat Hist Soc 1938;40:191-212.

23. Venkaiah M. Studies on the vegetation and flora of Vijayanagaram district. Ph. D Thesis, Andhra University, Visakhapatnam; 1980. 